KerLinger P., 2000 - An Assessment of the Impacts of Green Mountain Power Corporation's Searsburg, Vermont, Wind Power Facility on Breeding and Migrating Birds - Proceedings National Avain-Wind Power Planning Meeting III, San Diego, California, 1998. Pp. 90-96.

LeKuona J.M., 2001 - Uso del espacio por la avifauna y control de la mortalidad de aves y murcielagos en los parques eolicos de Navarra durante un ciclo annual - Informe Tecnico por el Departamento de Medio Ambiente, Ordenacion del Territorio y Vivienda, Gobierno de Navarra.

Marti' R.M. \& BarRios L., 1995 - Effects of wind turbine power plants on the avifauna in the campo de Gibraltar region - Summary of final report. Sociedad Espagnola de Ornitologia. $19 \mathrm{pp}$.

Paolo Forconi, Maurizio Fusari \& Annalisa Appiotti Studio Faunistico Ass.to Chiros - Via Nazionale, 67 - I-62010 Macerata E-mail: chiros.studio@libero.it

\title{
IMPACT OF PREDATION BY THE BLACK RAT, RATTUS RATTUS, ON THE BREEDING SUCCESS OF CORY'S SHEARWATER, CALONECTRIS DIOMEDEA, ON LINOSA ISLAND (SICILY, ITALY)
}

\footnotetext{
RIASSUNTO - Impatto della predazione del Ratto nero, Rattus rattus, sul successo riproduttivo della Berta maggiore, Calonectris diomedea, nell'isola di Linosa (Sicilia, Italia).

È stato studiato nel corso del 2006 nell'isola di Linosa (arcipelago delle Pelagie), l'impatto della predazione del Ratto nero sul successo riproduttivo della Berta maggiore. Sono stati individuati e controllati 231 nidi attivi in luglio, settembre ed ottobre. In luglio sono stati rinvenuti uova o pulli in 121 nidi e 80 uova furono predate. In settembre sono stati rinvenuti 91 uova o pulli, e 30 furono predati. Il successo riproduttivo è risultato del $39 \%$, la predazione del ratto del $59 \%$, le perdite naturali del $2 \%$.
}

\section{Introduction}

Black Rat, Rattus rattus, is one of the most common species on Mediterranean islands; it is found on all of the large and medium-sized islands, and on many of the smallest ones as well (PERFETTI et alii, 2001).

On Linosa, the Black Rat was introduced by man and its density is not evaluable at present. Linosa island hosts the largest breeding colony of Cory's Shearwater, Calonectris diomedea, in Italy (estimated at 10.000-15.000 pairs, IAPICHINO \& MASSA, 1989), and the second largest colony in the west-central Mediterranean (GRANADEIRo et alii, 1997). The aim of this work was to verify for the first time the limiting factors influencing breeding success in the Cory's Shearwater breeding colony on the island of Linosa, with special attention to the impact of Black Rats. 


\section{Data and Methods}

Linosa island $\left(35^{\circ} \mathrm{N}, 12^{\circ} 52^{\prime} \mathrm{E}\right)$ is part of the Pelagie Islands, an archipelago located in the Sicilian Channel. The study was carried out throughout the breeding cycle of the Cory's Shearwater's colony:

- arrival at the colony (March-April),

- egg laying (May-June),

- hatching (July),

- feeding of chicks (July-October)

- fledging (October) for a total of 65 days.

To verify Black Rat predation, we monitored nests periodically in July (hatching and to register losses), September (grown chicks and to register losses) and October (fledglings).

We chose the $6^{\text {th }}$ of June to begin the study on Black Rat predation, because Cory's Shearwater eggs laid during the last decade of May were already incubated and consequently of no interest for egg collecting, one of the major impact causes recorded in the past.

We could thus be sure that any missing eggs were to be attributed to Black Rat predation.

\section{Conclusion}

In the period between the $6^{\text {th }}$ and the $10^{\text {th }}$ June 2006, we found and mapped 231 Cory's Shearwater eggs.

In July we found 121 eggs or pulli, 4 abandoned eggs, 1 crushed egg, 80 predated eggs, and 23 predated chicks; in two cases adults were present without eggs or chicks. Several egg shells were found near the nests, often out in the open and showing clear marks from their predator's jaws. Egg shells were found on the ground, inside nests, out in the open on rocks or in Lycium intricatum bushes.

In September we observed 91 eggs or chicks, while 30 were predated (20 chicks and 10 eggs).

Twenty nests where chicks had been present were empty. Another 10 nests in which eggs had been present were empty, but it was not possible to determine whether it was the chick (most likely) or the egg that had been predated.

Reproductive success was therefore $39 \%$, rat predation (or overall mammal predation, allowing for the possibility of some predation by cats) was $59 \%$, and natural losses $2 \%$, indicated by the 4 abandoned eggs and 1 crushed egg that we found.

Acknowledgments - We are particularly thankful to Mr Salvatore Bonadonna and Mr Angelo Tuccio for their help and experience during field work.

We thank Mr Amodei of the Azienda Foreste Demaniali of Agrigento and Mr Alongi, for having supplied one unit personnel, Mr Roberto Bonadonna, allowing monitoring activities in some area while we were present on the island. This work was carried out thanks to financial support of LIPU UK. 
Granadeiro J.P, Massa B.,\& Lo Valvo M., 1997 - Cory's shearwater Calonectris diomedea. Pp. 20. In: HagemeiJer E.J.M. \& Blair M.J. (eds). The Ebcc atlas of European breeding birds, their distribution and Abundance - $T \& A D$ Poyser, London.

IAPIChino C. \& MAssa B., 1989 - The Birds of Sicily. British Ornithologists' Union - Check-list n. 11, London.

Perfetti A., Sposimo P. \& Baccetti N., 2001 - Il controllo dei ratti per la conservazione degli uccelli marini nidificanti nelle isole italiane e mediterranee - Avocetta, 25: 126.

Giuseppe Rannisi ${ }^{1}$, Loredana Murabito ${ }^{1}$, Marco Gustin ${ }^{1} \&$ Bruno Massa ${ }^{2}$ ${ }^{1}$ Conservation Department of LIPU (Italian League for the Protection of Birds) Via Trento, 49 - I-43100 Parma. E-mail: marco.gustin@lipu.it

${ }^{2}$ Stazione d'inanellamento, c/o Dipartimento SENFIMIZO Entomologia, Acarologia, Zoologia V.le Scienze, 13 - I-90128 Palermo

\section{AVIFAUNA NELLE AREE LIMITROFE ALL'OASI FAUNISTICA DI S. GAUDENZIO. PRIMO ANNO DI INDAGINE}

ABSTRACT - Birdlife in the Oasis of Protection of Fauna of S. Gaudenzio adjacent areas.

The Oasis of Protection of Fauna of S. Gaudenzio is in the territory of the Commune of Senigallia (Ancona), it is an area characterized by a great variety of environments. This work examines bird populations of conservation importance in adjacent areas. This area is hilly and cultivated. Among breeding birds are present Buteo buteo, Tyto alba and Emberiza hortulana.

\section{Introduzione}

L'Oasi Faunistica di San Gaudenzio (N $\left.43^{\circ} 41^{\prime} \mathrm{E} 13^{\circ} 11^{\prime}\right)$ è situata nel territorio comunale di Senigallia (Ancona) ed ha un'estensione di 32 ha. L'area, posta a $4 \mathrm{~km}$ dal mare ed a $2 \mathrm{~km}$ dal centro urbano di Senigallia, è un'ex cava di calcare-marnoso che presenta un'accentuata diversità ambientale dovuta alla passata attività di escavazione e alla rinaturalizzazione spontanea avvenuta dopo la chiusura della cava: si sono così venuti a formare ambienti umidi (due laghetti di ridotte dimensioni) e ambienti xerici. L'area interessata comprende il territorio esterno all'Oasi di San Gaudenzio per una distanza che va dai 200 ai 500 metri dai confini della stessa, l'altitudine varia dai 12 ai 150 metri s.l.m. L'area comprende le colline della sponda destra della bassa valle del fiume Misa caratterizzate da rocce di origine terziaria e quaternaria. Gran parte del territorio risulta antropizzato sia per uso coltivo che residenziale. Le zone coltivate sono spesso alternate da arbusteti, nuclei boschivi misti in cui predomina Quercus pubescens e Robinia pseudacacia ed aree incolte. 